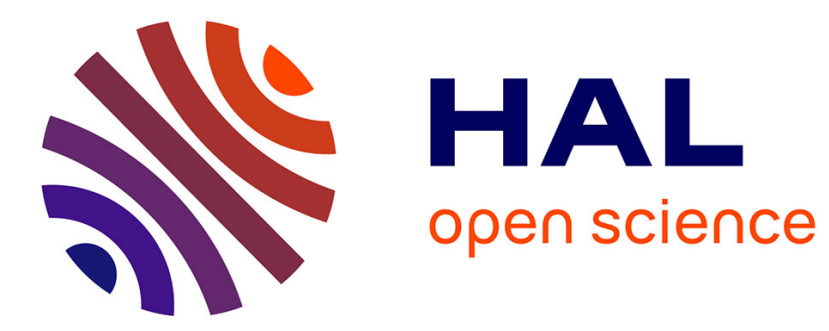

\title{
Araf51 with improved transglycosylation activities: One engineered biocatalyst for one specific acceptor
}

\author{
Alizé Pennec, Richard Daniellou, Pascal Loyer, Caroline Nugier-Chauvin, \\ Vincent Ferrières
}

\section{- To cite this version:}

Alizé Pennec, Richard Daniellou, Pascal Loyer, Caroline Nugier-Chauvin, Vincent Ferrières. Araf51 with improved transglycosylation activities: One engineered biocatalyst for one specific acceptor. Carbohydrate Research, 2015, 402, pp.50-55. 10.1016/j.carres.2014.10.031 . hal-01086640

HAL Id: hal-01086640

https://hal-univ-rennes1.archives-ouvertes.fr/hal-01086640

Submitted on 24 Nov 2014

HAL is a multi-disciplinary open access archive for the deposit and dissemination of scientific research documents, whether they are published or not. The documents may come from teaching and research institutions in France or abroad, or from public or private research centers.
L'archive ouverte pluridisciplinaire HAL, est destinée au dépôt et à la diffusion de documents scientifiques de niveau recherche, publiés ou non, émanant des établissements d'enseignement et de recherche français ou étrangers, des laboratoires publics ou privés. 


\section{Araf51 with improved transglycosylation activities: One engineered}

\section{biocatalyst for one specific acceptor.}

Alizé Pennec, ${ }^{\mathrm{a}, \mathrm{b}}$ Richard Daniellou, ${ }^{\mathrm{a}, \mathrm{b}, \S}$ Pascal Loyer, ${ }^{\mathrm{b}, \mathrm{c}}$ Caroline Nugier-Chauvin*, ${ }^{\mathrm{a}, \mathrm{b}}$ Vincent Ferrières ${ }^{*, a, b}$

${ }^{a}$ Ecole Nationale Supérieure de Chimie de Rennes, CNRS, UMR 6226, 11 Allée de Beaulieu, CS 50837, 35708 Rennes Cedex 7, France

${ }^{\mathrm{b}}$ Université européenne de Bretagne, France

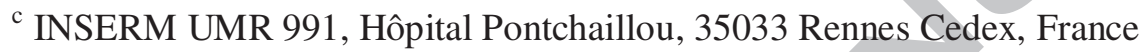

Abstract: A random mutagenesis of the arabinofuranosyl hydrolase Araf51 has been run in order to access to efficient biocatalysts for the synthesis of alkyl arabinofuranosides. The mutants were selected on their ability to catalyze the transglycosylation reaction of $p$ nitrophenyl $\alpha$-L-arabinofuranoside ( $p$ NP-Araf) used as a donor and various aliphatic alcohols as acceptors. This screening strategy underlined 5 interesting clones, each one corresponding to one acceptor. They appeared to be much more efficient in the transglycosylation reaction compared to the wild type enzyme whereas no self-condensation or hydrolysis products could be detected. Moreover, the high specificity of the mutants towards the alcohols for which they have been selected validates the screening process. Sequence analysis of the mutated enzymes revealed that, despite their location far from the active site, the mutations affect significantly

\footnotetext{
*Corresponding author at: Ecole Nationale Supérieure de Chimie de Rennes, CNRS, UMR 6226, 11 Allée de Beaulieu, CS 50837, 35708 Rennes Cedex 7, France. Tel.: 33(0)2 23238066. Email address: caroline.nugier@ensc-rennes.fr

${ }^{\S}$ Present address: Institut de Chimie Organique et Analytique (ICOA), UMR CNRS 7311, Université d'Orléans, BP 6759, Rue de Chartres, 45067 Orléans Cedex 2, France
} 
the kinetics properties as well as the substrate affinity of these mutants towards the alcohol acceptors in the transglycosylation reaction.

Keywords: Furanosides, Transglycosylation, Random mutagenesis, Furanosidase

\section{Introduction}

One of the current needs in chemical research is the development of greener and more eco-friendly reactions. The glycosylation is an example thereof, being one of the most important and difficult reactions for biomolecules synthesis. Indeed, it still remains a challenge in chemistry requiring multiple reaction steps and the use of various protecting groups. In Nature there are multiple enzymes as glycosyltransferases, polysaccharide lyases and glycosidases able to assemble or cleave easily the glycosidic bond with high regioselectivity. ${ }^{1}$ Nowadays, biotechnological approaches are recognized as powerful tools for the synthesis of glycoconjugates and improving biocatalyst efficiency seems to be one of the most promising approaches..$^{2-7}$ Moreover it is noteworthy that the chemical synthesis of arabinofuranosides with a high degree of stereocontrol and without any pyranosidic forms, suffers from a lack of generality. For instance the synthesis of alkyl arabinofuranosides is generally obtained from the key intermediates per-O-protected furanoses. ${ }^{8-10}$ However, biocatalyzed furanosylation has been recently developed and its versatility was further extended to the preparation of non-natural furanosyl-containing conjugates (for a review, see reference ${ }^{11}$ ). Indeed, glycosidases are good candidates in comparison to other enzymes, thanks to their stability, ease of production and low-cost of substrates which can be bio-sources. A recent example of directed evolution was applied to the $\beta$ glycosidase of Thermus thermophilus in order to increase its ability to synthesize oligopyranosides vs. its hydrolytic activity. ${ }^{12-14}$ To achieve these results, Koné et al. developed a high-throughput digital imaging screening methodology to detect transglycosidase mutants in E. coli cells. ${ }^{14}$ Herein, we adapted and completed this kind of screening to improve arabinofuranosyl transglycosylation with the aim to apply it to a wide range of aliphatic alcohols (Scheme 1). As a model reaction, we chose to synthesize alkyl $\alpha$-L-arabinofuranosides which are simple molecules with diverse properties and potential uses. Depending on the nature of the alkyl chain, they find 
applications as immunostimulating agents or antiparasitic drugs. ${ }^{15-17}$ More generally, the alkyl pyranosidic counterparts act as chemical building blocks for further derivatization and industrial preparation of alkyl polyglycosides. ${ }^{18,19}$

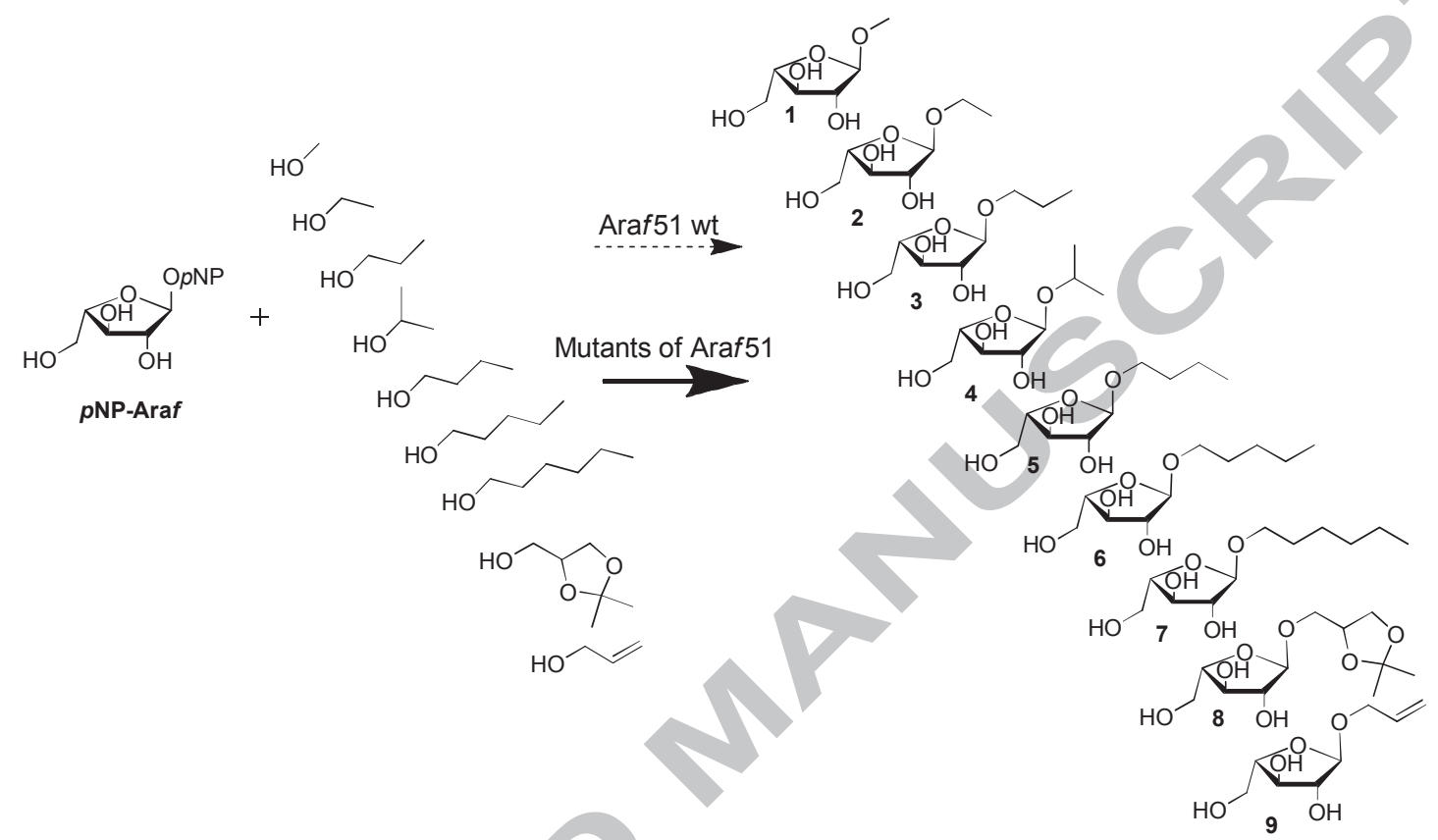

Scheme 1. Enzymatic synthesis of alkyl $\alpha$-L-arabinofuranosides.

In this context, we performed random mutagenesis on the $\alpha$-L-arabinofuranosidase (Araf51) from Clostridium thermocellum in an attempt to improve the transglycosylation activities for the synthesis of alkyl $\alpha$-L-arabinofuranosides. For the selection of suitable variants, a screening in two steps has been developed. The initial one, directly on plates, allowed colony selection of mutants with good hydrolytic activity on an Araf-containing chromogenic substrate. Indeed in order to maintain the physical quality of the agar gels and cells viability, the presence of alcohols as acceptors was excluded for this first screening step. The second one assessed the transglycosylation activities towards the convenient alcohol acceptor of the previous selected enzymes by 96 -well spectrophotometry. In this approach, one of the main objectives was to obtain mutants with high selectivity towards nucleophilic alcohols: one specific mutant for one specific acceptor. 


\section{Results and discussion}

\subsection{Identification of mutants with improved transglycosylation abilities.}

The thermostable arabinofuranosyl hydrolase, Araf51, naturally removes $\alpha-(1 \rightarrow 2), \alpha-(1 \rightarrow 3)$ and $\alpha$ $(1 \rightarrow 5)$-linked L-arabinofuranosyl units from arabinans and arabinoxylans. To the best of our knowledge, this enzyme belongs to the only arabinofuranosidase family (GH51) showing the ability to catalyze transglycosylation reactions. In addition, Araf51 has been described several times for its substrate versatility as it recognizes arabinofuranosides as well as galactofuranosides. ${ }^{17,20-23}$ Preliminary experiments showed the ability of the Araf51 wild type (wt) to transglycosylate $p$ NP-Araf to small aliphatic alcohol in order to obtain alkyl $\alpha$-L-arabinofuranosides. ${ }^{24}$ However, the activity strongly decreased when acceptors contain more than 3 carbons in their chain. With the aim to improve the transglycosylation activity towards aliphatic alcohols, mutants were thus created by random mutagenesis and selected from a simple screening procedure.

Firstly, a library of mutated Araf51 genes has been generated by error prone PCR and cloned into pCR® 2.1-TOPO® vector. After cell transformations, E. coli BL21 DE3 clones were spread on LB plates for the screening. This latter consisted in a first selection of positive colonies overexpressing an active Araf51. During this step, the colonies were platted on LB media containing IPTG and $1.5 \mathrm{mM}$ of 5-bromo-indolyl $\alpha$-L-arabinofuranosyl. ${ }^{25}$ This molecule is hydrolyzed by the Araf51 releasing a blue air-oxidized di-indolyl compound. In this way, the colonies staining in blue expressed enzymes successfully cloned which still recognize the arabinofuranosyl moiety as donor. Ideally, mutants that tend to favor transglycosylation were supposed to perform slow aglycon release in the absence of a suitable acceptor and therefore display a pale blue staining. Nevertheless, a low expression level of some mutated enzymes could also result in a pale coloration. Also, the selection of all the blue colonies was performed and the transglycosylation properties of the resulting enzymes assayed.

This first step allowed us to select more than 120 colonies for further expression of the mutated enzymes. The corresponding cell free extracts were heated at $70{ }^{\circ} \mathrm{C}$ to remove most of the $E$. coli derived proteins and also confirmed the thermostability of the selected mutants. In the second step of 
the screening procedure, each enzyme was tested in the presence of $p$ NP-Ara $f$ and an alcohol in order to evaluate their transglycosylation ability (T) over hydrolysis potential (H) (Scheme 2). UVmeasurements were performed during the initial time where the deglycosylation of the glycosylenzyme intermediate is the rate-limiting step. If the transglycosylation is favored, the initial speed rate in these conditions should be higher than the one during the hydrolysis. The initial reaction rates were determined thanks to the release of $p$-nitrophenol $(405 \mathrm{~nm})$. For each cell free extract, two types of reaction were performed, in presence and absence of alcohol acceptor. The alcohol volume was up to $25 \%(\mathrm{v} / \mathrm{v})$ to limit the presence of water, and so to favor as much as possible the target transglycosylation. DMSO was added to the reaction mixture as an optimized solubility factor for aliphatic alcohol. Reactions were performed at $\mathrm{pH} 8$ to ensure maintaining the phenolate form of the leaving group and thus proper UV-visible monitoring. A range of linear alcohols were tested from methanol to $n$-hexanol as well as $i$-propanol, allylic alcohol and solketal.

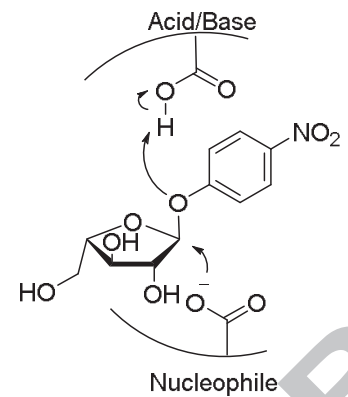

Nucleophile
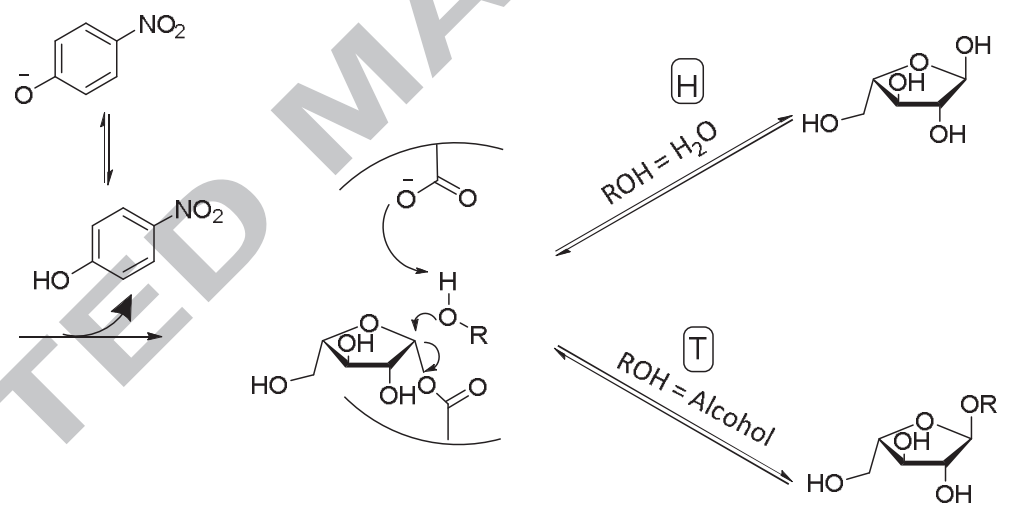

$\mathrm{R}=\mathrm{CH}_{3}-\left(\mathrm{CH}_{2}\right)_{\mathrm{n}^{-}}, \mathrm{CH}\left(\mathrm{CH}_{3}\right)_{2}, \mathrm{CH}_{2}-\mathrm{CH}=\mathrm{CH}_{2}$, ,

Scheme 2. Araf51-catalyzed transglycosylation with $p$ NP-Ara $f$ as donor and alcohols as acceptors.

To easily reveal interesting enzymes, the initial speed rates obtained (Vi) were normalized with the one corresponding to the wild type. Then, a ratio $\mathrm{R}$ was calculated correlating directly to the increase of activity in presence of the acceptor (Equation 1).

$$
\mathrm{R}=\frac{V i \mathbf{H}+\mathbf{T}}{V i \mathbf{H}} \quad(\text { Equation } 1)
$$


with $V i_{\mathbf{H}+\mathbf{T}}$ corresponds to the initial rate in presence of alcohol, and $V i_{\mathbf{H}}$ to the initial rate without alcohol.

For each alcohol tested, around twenty mutants showed positive activation with $\mathrm{R}$ value above 1 . In order to detect these mutants with potentially better transglycosylation than the wild type, analytic time course reactions were performed and conversions (Table 1) determined by NMR spectroscopy: the protons corresponding to the $p \mathrm{NP}$ group are up-field shifted when released, and the appearance of a new anomeric proton from the product was clearly observed (see supplementary materials). On this basis, we focused our attention on five mutants. Then preparative reactions were performed, and the transglycosylation products were isolated by column chromatography (Table 1). The alkyl resulting $\alpha$ L-arabinofuranosides were characterized by ${ }^{1} \mathrm{H}$ and ${ }^{13} \mathrm{C}$ NMR analysis. These data were in accordance with previously recorded results for compounds $\mathbf{1 - 5}, \mathbf{9}^{26-28}$ and new furanosides 6-8 were fully described in the experimental part.

Table 1. Conversions and yields by transglycosylation using Araf51 wt and selected mutants for different alcohol acceptors.

\begin{tabular}{|c|c|c|c|c|c|c|c|}
\hline \multirow[t]{3}{*}{ Entry } & \multirow[t]{3}{*}{ Acceptor } & \multirow{3}{*}{$\begin{array}{l}\text { Araf51 wt } \\
\text { Conversion }^{\mathrm{a}}\end{array}$} & \multirow{3}{*}{$\begin{array}{l}\text { Time } \\
\text { (min) }\end{array}$} & \multicolumn{3}{|l|}{ Mutant } & \multirow[t]{3}{*}{ Improvement $^{\mathrm{c}}$} \\
\hline & & & & Conversion $^{\mathrm{a}}$ & Time & Yield $^{\mathrm{b}}$ & \\
\hline & & & & $(\%)$ & $(\min )$ & $(\%)$ & \\
\hline 1 & $\mathrm{MeOH}$ & 95 & 60 & - & - & - & \\
\hline 2 & $\mathrm{EtOH}$ & 90 & 60 & - & - & - & \\
\hline 3 & $n-\mathrm{PrOH}$ & 85 & 120 & 96 (M20) & 60 & 60 & $+13 \%$ \\
\hline 4 & $i-\mathrm{PrOH}$ & 30 & 120 & 38 (M22) & 60 & 30 & $+27 \%$ \\
\hline 5 & Solketal & 38 & 120 & - & - & - & \\
\hline 6 & AllOH & 76 & 120 & - & - & - & \\
\hline 7 & $n-\mathrm{BuOH}$ & 42 & 50 & 92 (M12) & 20 & 68 & $+119 \%$ \\
\hline 8 & $n$-PentOH & 72 & 120 & 96 (M60) & 120 & 80 & $+33 \%$ \\
\hline
\end{tabular}




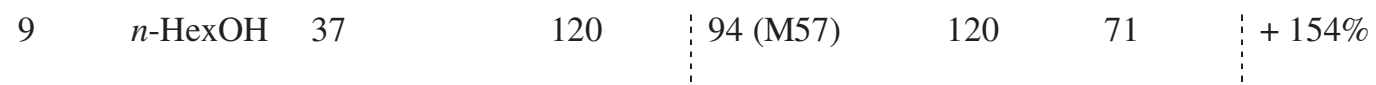

${ }^{\mathrm{a}}$ Conversion in transglycosylated product; ${ }^{\mathrm{b}}$ Isolated yield; ${ }^{\mathrm{c}} \mathrm{W}$ as obtained as $100 \mathrm{x}($ Conversion mutant Conversion wt)/Conversion wt.

Data from Table 1 firstly showed that moderate (i-propanol, solketal, $n$-butanol, $n$-hexanol) to excellent (methanol, ethanol) conversions in transglycosylated derivatives were generally obtained using the wild type biocatalyst but long reaction times were required (up to 2 hours). Secondly, it is important to note that no autocondensation product has been observed, probably due to the high concentration of alcohol acceptor that favored the desired transglycosylation. Subsequently, the mutation procedure of Araf51 wt enabled the isolation of 5 mutants with significant improved transglycosylation activities for $n$ - propanol, $i$ - propanol, $n$ - butanol, $n$-pentanol, and $n$ - hexanol (entries $3,4,7,8,9$, respectively). In comparison to the native enzyme, the engineered biocatalysts were all more promising in term of reaction time and conversion in tranglycosylation, with improvement from $+13 \%$ for M20 (n-propanol, entry 3 ) to $+154 \%$ for M57 (n- hexanol, entry 9). As an example, time course evolution between the wild type biocatalyst and the M20 mutant was given in figure 1. Unfortunately, the proposed protocol did not afford improved biocatalyst for solketal and allyl alcohol. Nevertheless, under the transglycosylation conditions performed with the selected mutants, hydrolysis of the resulted arabinofuranosides was not observed, even over 120 minutes and after total consumption of the substrate. Finally, no other transglycosylation by-products (autocondensation) were observed, so that the targeted $\alpha$-L-arabinofuranosides were specifically formed, confirming the diastereoselectivity of the mutants according to the glycosidic bond, whatever the nature of the biocatalyst.
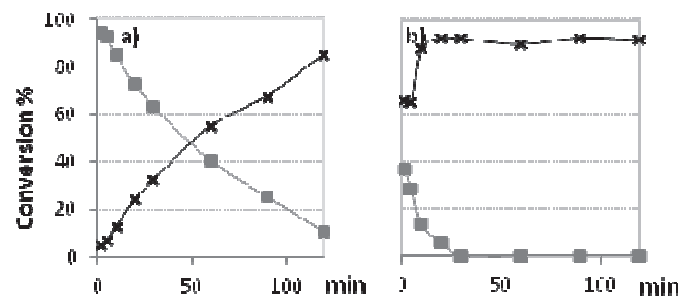
Figure 1. Time course of transglycosylation into propyl $\alpha$-L-arabinofuranoside (black) from $p$ NP-Araf (grey) by a) Araf51 wt and b) M20.

In order to evaluate the selectivity towards the aliphatic acceptor thanks to the mutated biocatalysts, transglycosylation reactions were performed with other structurally close alcohols (Table 2). It appeared that the mutants showed significantly better transglycosylation ability for the alcohol for which they were selected than for other acceptors. For instance, M20 mutant was particularly efficient and selective for $n$-propanol.

Table 2. Selectivity of the mutated enzymes (\% of transglycosylation conversion).

\begin{tabular}{llllcccc}
\hline Entry & Mutant & EtOH & $n-\mathrm{PrOH}$ & $i$-PrOH & $n-\mathrm{BuOH}$ & $n$-PentOH & $n-\mathrm{HexOH}$ \\
\hline 1 & M20 & 20 & $\mathbf{9 6}$ & 4 & 10 & & \\
2 & M22 & & 26 & $\mathbf{3 8}$ & 25 & & \\
3 & M12 & 19 & $\mathbf{9 2}$ & 35 & \\
4 & M60 & & 65 & $\mathbf{9 6}$ & 79 \\
5 & M57 & & & 65 & $\mathbf{9 4}$ \\
\hline
\end{tabular}

\subsection{Kinetic characterization and mutation identification of the selected enzymes}

Finally, the kinetic parameters of the different mutants were determined under hydrolysis conditions of $p$ NP-Araf at $25^{\circ} \mathrm{C}$ and $\mathrm{pH} 8(50 \mathrm{mM}$ Tris $\mathrm{HCl}$ buffer). Whereas Araf 51 is a thermophilic enzyme with $\mathrm{T}_{\mathrm{opt}}$ around $82{ }^{\circ} \mathrm{C}$, the parameters were determined at $25^{\circ} \mathrm{C}$ for practical reasons, as previously reported. ${ }^{29}$ The data presented in table 3 compares the values obtained with the Araf51 wt to the ones calculated for the selected enzymes. Most of the new biocatalysts showed lower $K_{\mathrm{m}}$ by comparison with the wild type, especially for M20 and M22. Furthermore, $k_{\text {cat }}$ values for the mutants were also lower than that for the wild type Araf51.

Table 3. Determination of Araf51 wt and selected mutants kinetic parameters for the hydrolysis reaction of $p \mathrm{NP}-\mathrm{Ara} f\left(\mathrm{pH} 8,50 \mathrm{mM}\right.$ of Tris $\mathrm{HCl}$ buffer, at $\left.25^{\circ} \mathrm{C}\right)$. 


\begin{tabular}{llll}
\hline Enzyme & $K_{\mathrm{m}}(\mathrm{mM})$ & $k_{\text {cat }}\left(\mathrm{s}^{-1}\right)$ & $k_{\text {cat }} / K_{\mathrm{m}}$ \\
\hline Araf51 wt & $0.34 \pm 0.08$ & $143 \pm 5$ & 420 \\
M20 & $0.07 \pm 0.02$ & $133 \pm 6.4$ & 1900 \\
M22 & $0.07 \pm 0.01$ & $20.9 \pm 1.2$ & 298 \\
M12 & $0.26 \pm 0.10$ & $93.8 \pm 12$ & 360 \\
M60 & $0.17 \pm 0.06$ & $118 \pm 8.7$ & 694 \\
M57 & $0.16 \pm 0.04$ & $73.6 \pm 4.7$ & 460
\end{tabular}

On a structural point of view, the crystal structure of the wild type enzyme has been previously solved (PDB file: 2C7F) and showed that two essential catalytic residues are required for the hydrolysis reaction were assigned as the acid/base residue Glu173 and the nucleophile Glu292. Moreover, structural information was also obtained from the co-crystallised of the inactive mutant E173A form of Araf51 with natural arabinotriose and arabinoxylobiose. ${ }^{29}$ These studies suggest little specificity for the exact orientation of the aglycone in the +1 subsite due to flexible conformation adopted by Trp 178 which stacks against the aglycone sugar unit. The sequence analysis of the mutants from this study revealed from one to six mutations (Table 4, see also supplementary data). It clearly appeared that the mutations were neither within the active site nor close to it. Nevertheless, concerning the biocatalyzed synthesis of the target alkyl arabinofuranosides, we expected that the alkyl chains could fit the entry of the common GH51 $(\beta / \alpha)_{8}$ barrel domain located at the extremity of the -1 subsite. Despite the location of the mutated sites, far from the active site, these mutations seemed to significantly affect the kinetics properties with regards to substrate affinity and transglycosylation reaction activity.

Table 4. Identified mutations.

\begin{tabular}{ll}
\hline Enzyme & Mutations \\
\hline M20 & R51G, V105L, T220S, S268T, A348S \\
M22 & P392S \\
M12 & K115T
\end{tabular}




\section{Conclusion}

Thanks to the coupling of random mutagenesis method conducted on the arabinofuranosyl hydrolase Araf51 and an efficient screening, we have obtained five mutants able to catalyze the transfer of an arabinofuranosyl entity to various aliphatic alcohols. In comparison to the wild type enzyme, these new biocatalysts improved the transglycosylation conversions up to $96 \%$. Additionally, the procedure used in the study yielded new biocatalysts with increased transglycosylation abilities and selectivity closely depending on the nature of the acceptor for which they were screened. This strategy was efficient with the aim of synthesizing valuable chemical building blocks such as alkyl $\alpha$-Larabinofuranosides. Additional benefits mutations in these rationally designed enzymes appeared to be distant from the active site. Further directed evolution experiments targeted on these observed mutations are now required in order to study the properties and catalytic abilities of the generated enzymes and to accurately understand the involvement of each modified site.

\section{Experimental}

\subsection{Expression and purification of Araf51 and mutant derivatives}

Plasmid pET28a (+) (Novagen) containing Araf51 wild type from Clostridium thermocellum ${ }^{29}$ and kanamycin resistance genes was provided by Prof G. Davies, University of York, U. K. Plasmid pCR®2.1-TOPO® $(3.9 \mathrm{~kb})$ from Invitrogen contains encoding mutated enzymes genes as well as ampicillin and kanamycin resistance genes. These plasmids were under the control of T7 promoter. The enzymes were produced in Escherichia coli BL21 DE3 cells (Invitrogen) cultured in LB (Lysogeny broth) plates containing $0.1 \mathrm{mM}$ of the corresponding selective agent at $37^{\circ} \mathrm{C} .10$ millitres of LB medium supplemented with antibiotic were inoculated with one single positive colony $E$. coli BL21 (DE3) and incubated overnight at $37{ }^{\circ} \mathrm{C}, 250 \mathrm{rpm}$. That was subsequently used to prepare $1 \%$ inoculum $\left(200 \mathrm{~mL} \mathrm{LB}+\right.$ antibiotic, $\left.250 \mathrm{rpm}, 37^{\circ} \mathrm{C}\right)$. Cells were grown to mid-exponential phase [Absorbance, $\mathrm{A}_{550}: 0.7$ ] at which point $i$-propyl $\beta$-D-thiogalactopyraoside (IPTG) was added to a final 
concentration of $1.0 \mathrm{mM}$ and the cultures were incubated for $14 \mathrm{~h}$ at $37{ }^{\circ} \mathrm{C}$. After centrifugation (20 min, $\left.4000 \mathrm{rpm}, 4^{\circ} \mathrm{C}\right)$, the cells were resuspended in $50 \mathrm{mM}$ Tris $\mathrm{HCl}$ buffer $\mathrm{pH} 8$ and sonicated $(3 \times$ $10 \mathrm{~s}$ ) for another centrifugation $\left(30 \mathrm{~min}, 20000 \mathrm{rpm}, 4{ }^{\circ} \mathrm{C}\right.$ ), the supernatant was heated at $70{ }^{\circ} \mathrm{C}$ for 15 min to remove a major amount of proteins and centrifuged again at $20000 \mathrm{rpm}$ for $30 \mathrm{~min}$. Protein concentrations were determined by the Bradford method. ${ }^{30}$ The purity of His-tagged Araf51 was confirmed by SDS-PAGE after Ni-NTA agarose affinity chromatography (Novagen, USA).

\subsection{Determination of Araf51 kinetic parameters}

The kinetic parameters $K_{\mathrm{m}}$ and $k_{\text {cat }}$ of Araf51 were quantified in triplicate by incubation of the enzyme (10 $\mu \mathrm{L}$ of $\approx 1 \mathrm{mg} / \mathrm{mL}$ ) with different concentrations of $p$-nitrophenyl $\alpha$-L-arabinofuranoside (6 to 0.02 $\mathrm{mM}$ ) in $50 \mathrm{mM}$ Tris $\mathrm{HCl}$ buffer $\mathrm{pH} 8$ at $25^{\circ} \mathrm{C}$. The release of $p$-nitrophenol was measured at $405 \mathrm{~nm}$ during 5 min (Microplates Spectrophotometer PowerWave XS/XS2, BioTek). The kinetic parameters were determined by calculations using GOSA software with repeatability.

\subsection{Random mutagenesis}

Random mutagenesis was performed by GeneMorph II Random Mutagenesis kit (Stratagene) using mutagenic PCR. The open reading frame encoding Araf51 was amplified using the primers:

- forward T7 Promoter TACGACTCACTATAGGGGAA and reverse T7 Promoter GCTAGTTATTGCTCAGCGGT (Strategy 1);

- forward T7 Promoter TACGACTCACTATAGGGGAA and reverse T7 Promoter GTGAGTCGTATTAATTTCGCGGT (Strategy 2).

For low mutation number (mutation frequency $0-4.5$ mutations / kb), $500 \mathrm{ng}$ of the initial target DNA were mixed with $250 \mathrm{ng}$ of each primer, $1 \mu \mathrm{L}$ of $40 \mathrm{mM}$ dNTP mix (final concentration of 800 $\mu \mathrm{M}$ each), $5 \mu \mathrm{L}$ of $10 \times$ Mutazyme II reaction buffer and $1 \mu \mathrm{L}$ of Mutazyme II DNA polymerase $(2.5$ $\mathrm{U} / \mu \mathrm{L}$ ) completed to $50 \mu \mathrm{L}$ with $\mathrm{H}_{2} \mathrm{O}$. The reaction was thermocycled as follows: one hot start cycle (95 $\left.{ }^{\circ} \mathrm{C}, 2 \mathrm{~min}\right)$ then 10 cycles: first the denaturing step $\left(95^{\circ} \mathrm{C}, 30 \mathrm{~s}\right)$, the hybridation step $\left(60{ }^{\circ} \mathrm{C}, 30 \mathrm{~s}\right)$ and the elongation step performed for $1 \mathrm{~min} / \mathrm{kb}\left(72{ }^{\circ} \mathrm{C}, 7 \mathrm{~min}\right.$ or $\left.10 \mathrm{~min}\right)$; and finally one cycle at $72{ }^{\circ} \mathrm{C}$ for $10 \mathrm{~min}$. Only for the second strategy, mutagenesis PCR products were directly cloned into a 
plasmid vector using the TOPO TA Cloning® Invitrogen protocol. The fresh PCR product $(2 \mu \mathrm{L})$ was mixed with the different reagents provided in the TOPO TA Cloning® Invitrogen kit: $1 \mu \mathrm{L}$ salt solution, $1 \mu \mathrm{L}$ pCR®2.1-TOPO® vector and $\mathrm{H}_{2} \mathrm{O}$ was added up to a final volume of $6 \mu \mathrm{L}$. The reaction was incubated for $5 \mathrm{~min}$ at room temperature $\left(22-23{ }^{\circ} \mathrm{C}\right)$.

\section{4. $\quad$ Screening of mutants}

The blue colonies were selected and cultivated in $5 \mathrm{~mL}$ LB media containing $0.1 \mathrm{mM}$ kanamycin LB media. The enzymes were purified as previously described and analyzed for their transglycosylation activities. As previously, protein concentration was estimated by Bradford method. Enzyme assays were performed to compare transglycosylation activities (presence of the alcohol acceptor) to hydrolytic activities (absence of the alcohol). Mutants and Araf51 wt enzymes were incubated in $\mathrm{pH} 8$ Tris $\mathrm{HCl} 50 \mathrm{mM}$ buffer with $20 \mathrm{mM}$ pNP-Araf, 20\% (v/v) DMSO, with or without 25\% (v/v) alcohol for a final volume of $140 \mu \mathrm{L}$ at $50{ }^{\circ} \mathrm{C}$. The final concentration in enzyme necessarily reached 0.017 $\mathrm{mg} / \mathrm{mL}$, thus the collected volume having to be adapted to each attempt following the determination of the initial concentration by the Bradford method. The release of $p$-nitrophenol was measured at 405 nm during 5 min (Microplate Spectrophotometer Powerwase XS/XS2, Biotek) and data evaluated with Gen5 Data Analysis Software (Biotek). The initial activities of the enzyme and mutated enzymes were determined using the monitoring of UV curves of the enzymatic assays. This enabled to compare the slope between Araf51 wt and the one of the mutants with or without the presence of alcohol acceptors, and highlighted the mutants of interest. Indeed, the mutated enzymes presenting a higher slope than the one of the Araf51 wt, in presence of alcohol, showed higher reaction activations, meaning that transglycosylation was preferred.

\subsection{Analytical scale of transglycosylation reactions, NMR kinetics}

Enzymatic reactions were run from $20 \mathrm{mM}$ pNP-Araf $(4.3 \mathrm{mg})$ and $200 \mu \mathrm{L}$ of alcohol acceptor incubated in pH 8 Tris $\mathrm{HCl} 50 \mathrm{mM}$ buffer with $160 \mu \mathrm{L}$ of DMSO. The enzyme preparation was added (a final concentration of $0.017 \mathrm{mg} / \mathrm{mL}$ is required) to the solution, and finally completed to a final volume of $800 \mu \mathrm{L}$ and maintained at $50{ }^{\circ} \mathrm{C}$ during $3 \mathrm{~h}$. Aliquots $(100 \mu \mathrm{L})$ of the enzymatic reaction 
mixture were withdrawn at several times and directly freezed with liquid nitrogen. After complete lyophilization, samples were solubilized in $500 \mu \mathrm{L}$ of $\mathrm{CD}_{3} \mathrm{OD}$ to enable the analysis by NMR. Transglycosylation activities using $p$ NP-Araf as glycosyl donor were determined by ${ }^{1} \mathrm{H}$ NMR. By monitoring the decrease of the $p$ NP-Araf signal (aromatic protons $\delta=8.21 \mathrm{ppm}$ and/or anomeric proton $\delta=5.66 \mathrm{ppm}$ ) and the release of $p$-nitrophenol (aromatic protons $\delta=8.12 \mathrm{ppm}$ ) corresponding to both the hydrolysis and the transglycosylation of the donor, the residual starting material can easily be quantified. The transglycosylation products were visualized by the emergence of the anomeric proton signal of the furanoside and/or the signal of the alkyl group protons. By reporting the relation between the proton signals, the resulting conversions were determined.

\subsection{General procedure for the synthesis of alkyl arabinofuranosides in a preparative scale}

Experiments were performed in $50 \mathrm{mM}$ Tris $\mathrm{HCl}$ buffer, $\mathrm{pH} 8$ at $50{ }^{\circ} \mathrm{C}$ in the presence of $p \mathrm{NP}$-Araf (30 mg, $0.11 \mathrm{mM}$ ), $1.4 \mathrm{~mL}$ of alcohol and $1.12 \mathrm{~mL}$ of DMSO in a total reaction volume of $5.6 \mathrm{~mL}$. Araf51 wild type or mutated was added to a final concentration of $0.017 \mathrm{mg} / \mathrm{mL}$ and the reaction was performed at $50{ }^{\circ} \mathrm{C}$ during the optimal duration determined at the analytical scale experiment. Then the mixture was concentrated under reduced pressure and the reaction products were separated by column chromatography on silica gel $\left(\mathrm{AcOEt} / \mathrm{AcOH} / \mathrm{H}_{2} \mathrm{O}, 50: 1: 1\right)$ affording the desired product.

\subsection{Purification and analysis of synthetic alkyl arabinofuranosides}

Thin layer chromatography (TLC) analysis were conducted on E. Merck $60 \mathrm{~F}_{254}$ Silica Gel non activated plates and compounds were visualized by UV ( $254 \mathrm{~nm}$ ), or a $5 \%$ solution of $\mathrm{H}_{2} \mathrm{SO}_{4}$ solution in EtOH containing orcinol, followed by heating. For column chromatography, Si 60 (40-63 $\mu \mathrm{m})$ Silica Gel was used. NMR spectra were recorded on a Bruker spectrometer ARX (400 MHz for ${ }^{1} \mathrm{H}$ and $100 \mathrm{MHz}$ for ${ }^{13} \mathrm{C}$ ). Chemicals shifts are expressed in $\delta$ units (ppm). Chemical shifts are calculated in Hertz and pattern abbreviations are as follows: $\mathrm{s}$ (singlet), $\mathrm{d}$ (doublet), $\mathrm{t}$ (triplet), $\mathrm{q}$ (quartet), $\mathrm{m}$ (multiplet), dd (double doublet)...The HRMS were measured with a MicrO-Tof-Q 2 (Bruker) equipped with electrospray and APCI ionization sources, two quadrupole-orthogonal accelerators and reflection 
time-of-flight analyzer, or a Q-tof 2 (Waters) equipped with electrospray ionization source, two quadrupole-orthogonal accelerators and reflection time-of-flight analyzer.

4.8. $\quad n$-Pentyl $\alpha$-L-arabinofuranoside (6)

$n$-Pentyl $\alpha$-L-arabinofuranoside 6 was obtained according to the described general procedure for transglycosylation by incubation of $n$-pentanol in the presence of the Araf51, and was isolated in $66 \%$ yield (16.1 mg) after purification by column chromatography. ${ }^{1} \mathrm{H}$ NMR $\left(\mathrm{CD}_{3} \mathrm{OD}\right): \delta 4.84\left(\mathrm{~d}, 1 \mathrm{H}, J_{1,2}=2.0 \mathrm{~Hz}, \mathrm{H}-1\right), 3.94\left(\mathrm{dd}, 1 \mathrm{H}, J_{2,3}=4.0 \mathrm{~Hz}, \mathrm{H}-2\right), 3.92-3.89(\mathrm{~m}$, $1 \mathrm{H}, \mathrm{H}-4), 3.82\left(\mathrm{dd}, 1 \mathrm{H}, J_{3,4}=6.4 \mathrm{~Hz}, \mathrm{H}-3\right), 3.73\left(\mathrm{dd}, 1 \mathrm{H}, J_{4,5}=3.2 \mathrm{~Hz}, J_{5 \mathrm{a}, 5 \mathrm{~b}}=12.0 \mathrm{~Hz}, \mathrm{H}-\right.$ 5a), $3.71\left(\mathrm{dt}, 1 \mathrm{H}, J_{\mathrm{CH} 2, \mathrm{CH} 2}=10.0 \mathrm{~Hz}, J_{\mathrm{CH} 2, \mathrm{CH} 2}=6.4 \mathrm{~Hz}, \mathrm{OCH}_{2} \mathrm{CH}_{2}\right), 3.62\left(\mathrm{dd}, 1 \mathrm{H}, J_{4,5 \mathrm{~b}}=5.2\right.$ $\mathrm{Hz}, \mathrm{H}-5 \mathrm{~b}), 3.41\left(\mathrm{dt}, 1 \mathrm{H}, J_{\mathrm{CH} 2, \mathrm{CH} 2}=9.6 \mathrm{~Hz}, J_{\mathrm{CH} 2, \mathrm{CH} 2}=6.8 \mathrm{~Hz}, \mathrm{OCH}_{2} \mathrm{CH}_{2}\right), 1.61-1.57(\mathrm{~m}, 2 \mathrm{H}$, $\left.\mathrm{OCH}_{2} \mathrm{CH}_{2}\right), 1.36-1.34\left(\mathrm{~m}, 4 \mathrm{H}, \mathrm{CH}_{2} \mathrm{CH}_{2} \mathrm{CH}_{3}\right), 0.92\left(\mathrm{t}, 3 \mathrm{H}, J_{\mathrm{CH} 2, \mathrm{CH} 3}=7.2 \mathrm{~Hz}, \mathrm{CH}_{3}\right) .{ }^{13} \mathrm{C} \mathrm{NMR}$ $\left(\mathrm{CD}_{3} \mathrm{OD}\right): \delta 109.4(\mathrm{C}-1), 85.1(\mathrm{C}-4), 83.6(\mathrm{C}-2), 78.7(\mathrm{C}-3), 68.8\left(\mathrm{OCH}_{2} \mathrm{CH}_{2}\right), 63.0(\mathrm{C}-5)$, $30.4\left(\mathrm{OCH}_{2} \mathrm{CH}_{2}\right), 29.5\left(\mathrm{CH}_{2} \mathrm{CH}_{2} \mathrm{CH}_{3}\right), 23.5\left(\mathrm{CH}_{2} \mathrm{CH}_{3}\right), 14.4\left(\mathrm{CH}_{3}\right) . \mathrm{HRMS}\left(\mathrm{ESI}^{+}\right): \mathrm{m} / \mathrm{z}$ calcd for $\mathrm{C}_{10} \mathrm{H}_{20} \mathrm{O}_{5} \mathrm{Na}[\mathrm{M}+\mathrm{Na}]^{+} \mathrm{m} / \mathrm{z} 243.1208$; found, m/z 243.1676.

4.9. n-Hexyl $\alpha$-L-arabinofuranoside (7)

$n$-Hexyl $\alpha$-L-arabinofuranoside 7 was obtained according to the described general procedure for transglycosylation by incubating $n$-hexanol in the presence of the Araf51 wt. It was isolated in $71 \%$ yield (18.5 mg) after purification by column chromatography. ${ }^{1} \mathrm{H}$ NMR $\left(\mathrm{CD}_{3} \mathrm{OD}\right): \delta 4.84\left(\mathrm{~d}, 1 \mathrm{H}, J_{1,2}=2.0 \mathrm{~Hz}, \mathrm{H}-1\right), 3.94\left(\mathrm{dd}, 1 \mathrm{H}, J_{2,3}=4.0 \mathrm{~Hz}, \mathrm{H}-2\right), 3.92-3.90(\mathrm{~m}$, $1 \mathrm{H}, \mathrm{H}-4), 3.82\left(\mathrm{dd}, 1 \mathrm{H}, J_{3,4}=6.4 \mathrm{~Hz}, \mathrm{H}-3\right), 3.74\left(\mathrm{dd}, 1 \mathrm{H}, J_{4,5}=3.2 \mathrm{~Hz}, J_{5 \mathrm{a}, 5 \mathrm{~b}}=12.0 \mathrm{~Hz}, \mathrm{H}-\right.$ 5a), $3.71\left(\mathrm{dt}, 1 \mathrm{H}, J_{\mathrm{CH} 2, \mathrm{CH} 2}=6.8 \mathrm{~Hz}, J_{\mathrm{CH} 2, \mathrm{CH} 2}=9.6 \mathrm{~Hz}, \mathrm{OCH}_{2} \mathrm{CH}_{2}\right), 3.62\left(\mathrm{dd}, 1 \mathrm{H}, J_{4,5 \mathrm{~b}}=5.6\right.$ $\mathrm{Hz}, \mathrm{H}-5 \mathrm{~b}), 3.41\left(\mathrm{dt}, 1 \mathrm{H}, J_{\mathrm{CH} 2, \mathrm{CH} 2}=9.6 \mathrm{~Hz}, J_{\mathrm{CH} 2, \mathrm{CH} 2}=6.4 \mathrm{~Hz}, \mathrm{OCH}_{2} \mathrm{CH}_{2}\right), 1.60-1.57(\mathrm{~m}, 2 \mathrm{H}$, $\left.\mathrm{OCH}_{2} \mathrm{CH}_{2}\right), 1.35-1.32\left(\mathrm{~m}, 6 \mathrm{H}, \mathrm{CH}_{2} \mathrm{CH}_{2} \mathrm{CH}_{2} \mathrm{CH}_{3}\right), 0.91\left(\mathrm{t}, 3 \mathrm{H}, J_{\mathrm{CH} 2, \mathrm{CH} 3}=6.8 \mathrm{~Hz}, \mathrm{CH}_{3}\right) .{ }^{13} \mathrm{C}$ 
NMR (CD 3 OD): $\delta 109.4(\mathrm{C}-1), 85.1$ (C-4), 83.6 (C-2), $78.7(\mathrm{C}-3), 68.8\left(\mathrm{OCH}_{2} \mathrm{CH}_{2}\right), 63.0(\mathrm{C}-$ 5), $32.8\left(\mathrm{OCH}_{2} \mathrm{CH}_{2}\right), 30.7\left(\mathrm{CH}_{2} \mathrm{CH}_{2} \mathrm{CH}_{2} \mathrm{CH}_{3}\right), 26.9\left(\mathrm{CH}_{2} \mathrm{CH}_{2} \mathrm{CH}_{3}\right), 23.7\left(\mathrm{CH}_{2} \mathrm{CH}_{3}\right), 14.4$ $\left(\mathrm{CH}_{3}\right)$. HRMS (ESI $\left.{ }^{+}\right)$: calcd for $\mathrm{C}_{11} \mathrm{H}_{22} \mathrm{O}_{5} \mathrm{Na}[\mathrm{M}+\mathrm{Na}]^{+} \mathrm{m} / \mathrm{z}$ 257.1365; found, m/z 257.1915.

\subsection{3-O- $\alpha$-L-arabinofuranosyl-O-isopropylidene-sn-glycerol (8)}

The desired furanoside $\mathbf{8}$ was obtained according to the general procedure for transglycosylation by incubation of solketal in the presence of the Araf51 wt. After chromatographic purification, it was isolated in $36 \%$ yield $(10.5 \mathrm{mg}) .{ }^{1} \mathrm{H}$ NMR $\left(\mathrm{CD}_{3} \mathrm{OD}\right): \delta 4.92\left(\mathrm{~d}, 1 \mathrm{H}, J_{1,2}=1.6 \mathrm{~Hz}, \mathrm{H}-1\right), 4.31-$ $4.27\left(\mathrm{~m}, 1 \mathrm{H}, \mathrm{CH}_{2} \mathrm{CHCH}_{2}\right), 4.05(\mathrm{ddd}, 1 \mathrm{H}, J=2.4 \mathrm{~Hz}, J=6.8 \mathrm{~Hz}, J=8.4 \mathrm{~Hz}, \mathrm{O}-$ $\left.1 \mathrm{CH}_{2} \mathrm{CHCH}_{2} \mathrm{O}\right), 3.99\left(\mathrm{dd}, 1 \mathrm{H}, J_{2,3}=3.6 \mathrm{~Hz}, \mathrm{H}-2\right), 3.92-3.90(\mathrm{~m}, 1 \mathrm{H}, \mathrm{H}-4), 3.84\left(\mathrm{dd}, 1 \mathrm{H}, J_{3,4}=\right.$ $6.0 \mathrm{~Hz}, \mathrm{H}-3), 3.78-3.74\left(\mathrm{~m}, 2 \mathrm{H}, \mathrm{O}-1 \mathrm{CH}_{2} \mathrm{CH}-\mathrm{CH}_{2}, \mathrm{O}-1 \mathrm{CH}_{2}\right), 3.71\left(\mathrm{dd}, 1 \mathrm{H}, J_{4,5 \mathrm{a}}=5.2 \mathrm{~Hz}, J_{5 \mathrm{a}, 5 \mathrm{~b}}\right.$ $=12 \mathrm{~Hz}, \mathrm{H}-5 \mathrm{a}), 3.64\left(\mathrm{dd}, 1 \mathrm{H}, J_{4,5 \mathrm{~b}}=5.6 \mathrm{~Hz}, \mathrm{H}-5 \mathrm{~b}\right), 3.50-3.47\left(\mathrm{~m}, 1 \mathrm{H}, \mathrm{O}-1 \mathrm{CH}_{2}\right), 1.38(\mathrm{~s}, 3 \mathrm{H}$, $\left.\mathrm{CH}_{3}\right), 1.32\left(\mathrm{~s}, 3 \mathrm{H}, \mathrm{CH}_{3}\right) .{ }^{13} \mathrm{C} \mathrm{NMR}\left(\mathrm{CD}_{3} \mathrm{OD}\right): \delta 109.7(\mathrm{C}-1), 85.7(\mathrm{C}-4), 83.1$ (C-2), $78.8(\mathrm{C}-3)$, $75.9(\mathrm{CH}), 69.1\left(\mathrm{O}-1 \mathrm{CH}_{2} \mathrm{CH}\right), 67.6\left(\mathrm{O}-1 \mathrm{CH}_{2} \mathrm{CHCH}_{2}\right), 63.0(\mathrm{C}-5), 27.0\left(\mathrm{CH}_{3}\right), 25.6\left(\mathrm{CH}_{3}\right)$. HRMS $\left(\mathrm{ESI}^{+}\right)$: calcd for $\mathrm{C}_{11} \mathrm{H}_{20} \mathrm{O}_{7} \mathrm{Na}[\mathrm{M}+\mathrm{Na}]^{+} \mathrm{m} / \mathrm{z} 287.1107$; found, m/z 287.0985.

\section{Acknowledgments}

We are grateful to the Région Bretagne for a grant to A. P. We also thank Prof. G. J. Davies for providing the wild type and Jean-Paul Guégan (ENSCR) for recording NMR spectra.

\section{References}

(1) Lombard, V.; Golaconda Ramulu, H.; Drula, E.; Coutinho, P. M.; Henrissat, B. Nucleic Acids Res. 2014, 42, D490-D495.

(2) Armstrong, Z.; Withers, S. G. Biopolymers 2013, 99, 666-674.

(3) Cobucci-Ponzano, B.; Moracci, M. Nat. Prod. Rep. 2012, 29, 697-709. 
(4) Brian P. Rempel, M. B. T., Don J. Mahuran, and Stephen G. Withers Angew. Chem. Int. Ed. 2011, 50, 10381-10383.

(5) Kadokawa, J.-i. Chem. Rev. 2011, 111, 4308-4345.

(6) Hancock, S. M.; Rich, J. R.; Caines, M. E. C.; Strynadka, N. C. J.; Withers, S. G. Nature Chem. Biol. 2009, 508-514.

(7) Faijes, M.; Planas, A. Carbohydr. Res. 2007, 342, 1581-1594.

(8) Dureau, R.; Legentil, L.; Daniellou, R.; Ferrières, V. J. Org. Chem. 2012, 77, 1301-1307.

(9) Lowary, T. L. Curr. Opin. Chem. Biol. 2003, 7, 749-756.

(10) Sanchez, S.; Bamhaoud, T.; Prandi, J. Eur. J. Org. Chem. 2002, 3864-3873.

(11) Ferrières, V.; Nugier-Chauvin, C.; Legentil, L.; Tranchimand, S. In Carbohydrate Chemistry. Chemical and Biological approaches.; Rauter, A. P., Lindhorst, T., Queneau, Y., Eds.; 2014; Vol. 40, pp 401-417.

(12) Teze, D.; Hendrickx, J.; Czjzek, M.; Ropartz, D.; Sanejouand, Y.-H.; Tran, V.; Tellier, C.; Dion, M. Protein Eng. Des. Sel. 2014, 27, 13-19.

(13) Feng, H.-Y.; Drone, J.; Hoffmann, L.; Tran, V.; Tellier, C.; Rabiller, C.; Dion, M. J. Biol. Chem. 2005, 280, 37088-37097.

(14) Koné, F. M. T.; Le Béchec, M.; Sine, J.-P.; Dion, M.; Tellier, C. Protein Eng. Des. Sel. 2009, 22, 37-44.

(15) Suleman, M.; Gangneux, J.-P.; Legentil, L.; Belaza, S.; Cabezas, Y.; Manuela, C.; Dureau, R.; Sergent, O.; Burel, A.; Daligault, F.; Ferrières, V.; Robert-Gangneux, F. Antimicrob. Agents Chemother. 2014, 58, 2156-2166.

(16) Legentil, L.; Audic, J.-L.; Daniellou, R.; Nugier-Chauvin, C.; Ferrières, V. Carbohydr. Res. 2011, 346, 1541-1545.

(17) Chlubnová, I.; Filipp, D.; Spiwok, V.; Dvořáková, H.; Daniellou, R.; Nugier-Chauvin, C.; Králová, B.; Ferrières, V. Org. Biomol. Chem. 2010, 8, 2092-2102.

(18) von Rybinski, W.; Hill, K. Angew. Chem. Int. Ed. 1998, 37, 1328-1345. 
(19) Goodby, J. W.; Haley, J. A.; MacKenzie, G.; Watson, M. A. J.; Plusquellec, D.; Ferrières, V. J. Mater. Chem. 1995, 5, 2209-2220.

(20) Chlubnová, I.; Králová, B.; Dvořáková, H.; Hošek, P.; Spiwok, V.; Filipp, D.; NugierChauvin, C.; Daniellou, R.; Ferrières, V. Org. Biomol. Chem. 2014, 12, 3080-3089.

(21) Rémond, C.; Plantier-Royon, R.; Aubry, N.; Maes, E.; Bliard, C.; O'Donohue, M. J. Carbohydr. Res. 2004, 339, 2019-2025.

(22) Rémond, C.; Plantier-Royon, R.; Aubry, N.; O'Donohue, M. J. Carbohydr. Res. 2005, $340,637-644$.

(23) Rémond, C.; Ferchichi, M.; Aubry, N.; Plantier-Royon, R.; Portella, C.; O'Donohue, M. J. Tetrahedron Lett. 2002, 43, 9653-9655.

(24) Pennec, A.; Chlubnova, I.; Daniellou, R.; Ferrières, V.; Nugier-Chauvin, C. U.S. Provisional 2012, №61/636883.

(25) Berlin, W.; Sauer, B. Anal. Biochem. 1996, 243, 171-175.

(26) Finch, P.; Iskander, G. M.; Siriwardena, A. H. Carbohydr. Res. 1991, 210, 319-325.

(27) Mizutani, K.; Kasai, R.; Nakamura, M.; Tanaka, O.; Matsuura, H. Carbohydr. Res. 1989, $185,27-38$.

(28) Dutton, G. G. S.; Tanaka, Y.; Yates, K. Can. J. Chem. 1959, 37, 1955-1958.

(29) Taylor, E. J.; Smith, N. L.; Turkenburg, J. P.; D'Souza, S.; Gilbert, H. J.; Davies, G. J. Biochem. J. 2006, 395, 31-37.

(30) Bradford, M. M. Anal. Biochem. 1976, 72, 248-254. 


\section{Araf51 with improved transglycosylation activities: One engineered}

\section{biocatalyst for one specific acceptor.}

Alizé Pennec, ${ }^{\mathrm{a}, \mathrm{b}}$ Richard Daniellou, ${ }^{\mathrm{a}, \mathrm{b}, * *}$ Pascal Loyer, ${ }^{\mathrm{b}, \mathrm{c}}$ Caroline Nugier-Chauvin*, ${ }^{\mathrm{a}, \mathrm{b}}$ Vincent Ferrières*,a,b

${ }^{a}$ Ecole Nationale Supérieure de Chimie de Rennes, CNRS, UMR 6226, 11 Allée de Beaulieu, CS 50837, 35708 Rennes Cedex 7, France

${ }^{\mathrm{b}}$ Université européenne de Bretagne, France

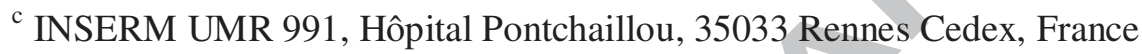

Araf51 with improved transglycosylation activities: One engineered biocatalyst for one specific acceptor

Alizé Pennec, Richard Daniellou, Pascal Loyer, Caroline Nugier-Chauvin, Vincent Ferrières

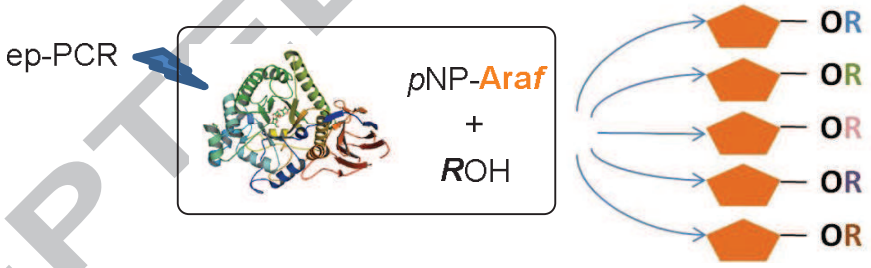

*Corresponding author at: Ecole Nationale Supérieure de Chimie de Rennes, CNRS, UMR 6226, 11 Allée de Beaulieu, CS 50837, 35708 Rennes Cedex 7, France. Tel.: 33(0)2 23238066. Email address: caroline.nugier@ensc-rennes.fr

** Present address: Institut de Chimie Organique et Analytique (ICOA), UMR CNRS 7311, Université d'Orléans, BP 6759, Rue de Chartres, 45067 Orléans Cedex 2, France 


\section{Araf51 with improved transglycosylation activities: One engineered}

\section{biocatalyst for one specific acceptor.}

Alizé Pennec, ${ }^{a, b}$ Richard Daniellou, ${ }^{a, b, \dagger \dagger}$ Pascal Loyer, ${ }^{\text {b,c }}$ Caroline Nugier-Chauvin*, a,b Vincent Ferrières $^{*, a, b}$

a Ecole Nationale Supérieure de Chimie de Rennes, CNRS, UMR 6226, 11 Allée de Beaulieu, CS 50837, 35708 Rennes Cedex 7, France

${ }^{\mathrm{b}}$ Université européenne de Bretagne, France

c INSERM UMR 991, Hôpital Pontchaillou, 35033 Rennes Cedex, France

\section{Highlights}

A random mutagenesis of Araf51 affords improved biocatalysts for transglycosylation. Five efficient mutated enzymes for the synthesis of alkyl furanosides. Each selected mutant is specific for one alcohol acceptor.

*Corresponding author at: Ecole Nationale Supérieure de Chimie de Rennes, CNRS, UMR 6226, 11 Allée de Beaulieu, CS 50837, 35708 Rennes Cedex 7, France. Tel.: 33(0)2 23238066. Email address: caroline.nugier@ensc-rennes.fr

${ }^{\dagger \dagger}$ Present address: Institut de Chimie Organique et Analytique (ICOA), UMR CNRS 7311, Université d'Orléans, BP 6759, Rue de Chartres, 45067 Orléans Cedex 2, France 